\title{
Combining the Hazards of Ministerial Appointment AND Ministerial Exit in the Canadian Federal Cabinet
}

\author{
Matthew Kerby Memorial University
}

\section{Introduction}

When the Progressive Conservative party under the leadership of John Diefenbaker won the 1957 Canadian general election, it marked a sea change in the Canadian political landscape. Prior to the election, the Liberal party served as the "governing party" for 22 years, first under Mackenzie King, Canada's longest serving prime minister and then under his successor Louis St-Laurent. By 1957 the Liberal era had run its course. King was dead, St-Laurent was old, the war was over and many of the usual cast of characters who had played leading roles in Canadian federal politics were either dead, old or had concluded their wars. Canadians, too, had grown tired of the Liberals and wanted change. The steadiness and calm that typified St-Laurent's ministry, by the end, had withered in a series of political scandals and boredom; the voters chose to give the alternative a chance by voting in the Progressive Conservative minority government in 1957 . Nine months later the minority government was terminated by the decisive 1958 election in which the Tories secured the largest majority in Canadian political history. Diefenbaker was thrilled. As a small-town Saskatchewan lawyer, his previous attempts at electoral politics had been largely unsuccessful. When he was selected leader of the hapless Progressive Conservative party in 1956, few expected him to succeed let alone resoundingly defeat the Liberal juggernaut.

Acknowledgments: The author acknowledges the helpful comments and suggestions made by Keith Dowding, Indridi Indridason, Hanna Back, Patrick Dumont, Ken Benoit, Gary Sneddon, Marina McGale, Denise Ledoux and the three anonymous CJPS reviewers. Thanks to Mark Williams who provided able research assistance.

Matthew Kerby, Department of Political Science, Memorial University of Newfoundland, St. John's, Newfoundland and Labrador, A1C 5S7, Canada, kerbym@mun.ca 
The Progressive Conservative party was elected to government on June 10, 1957; Diefenbaker had won the battle but he was poised to lose a war. When it came time to appoint his cabinet, Diefenbaker faced the unprecedented task of having to select his ministers from a large pool of freshly elected members of parliament (MPs) who not only had limited parliamentary experience but, more importantly, had no ministerial experience whatsoever. The situation was dire enough that Diefenbaker appointed himself as the minister of foreign affairs and the president of the Privy Council and he had not filled key portfolios several months after the Governor General swore in his first cabinet. Two months after the general election, Canada's national newspaper, The Globe and Mail, speculated on its front page that "Mr. Diefenbaker is still holding open the health and welfare portfolio and three cabinet ministershimself, Mr. Fulton and Mr. Harkness filling two posts each-is bound to bring renewal of the Liberal claims that the Conservatives can't find men to fill the positions" (Davey, 1957: 2).

Prime Minister Joe Clark faced a similar situation in 1979 when the Progressive Conservatives formed a minority government. His party had been out of power since the Progressive Conservatives' defeat in the 1963 election. Of the 136 government party MPs elected to the 31 st parliament, only five of them had served as cabinet ministers under Diefenbaker.

The Clark ministry's short duration ${ }^{1}$ did not help his successor, Brian Mulroney, when it came time to select his cabinet after he led the Progressive Conservative party to a landslide victory in 1984. While it is true that 22 of the 38 ministers appointed to the first Mulroney cabinet possessed ministerial experience, the total amount of ministerial experience for every one of those ministers was capped at 272 days, the duration of the Clark ministry. Of those 272 days, Parliament only sat for 66 of them before its dissolution.

Finally, the Conservative party of Canada's 2006 election victory after 13 consecutive years of Liberal government left Prime Minister-elect Stephen Harper with a pool of potential ministers with no cabinet experience whatsoever; indeed, only a few of the newly elected government party MPs possessed governing party experience.

These prime ministers' predicaments raise an interesting question for students of ministerial career paths. By what criteria do prime ministers choose their ministers when the potential ministers have little political let alone ministerial experience on which to evaluate their potential success as a minister? Existing research (Kerby, 2009) highlights the significance of previous political experience when appointing ministers but no one has yet to explore this particular aspect of the appointment process. By addressing this question, we continue to expand our knowledge of how prime ministers select their cabinet ministers in the Canadian and, by extension, comparative contexts. 
Abstract. The Canadian federal cabinet stands out among Westminster parliamentary democracies because of the large number of first-time ministers who are appointed to cabinet without any previous parliamentary or political experience. Several explanations have been put forward to account for this peculiarity but no attempt has been made to examine how Canadian prime ministers overcome the information deficit associated with appointing ministers with no experience. How can prime ministers be confident that they are making the right choice? This paper explores the subject by estimating the survival functions of ministerial turnover for potential, but not yet appointed, cabinet ministers were they to survive to a defined political benchmark; these survival rates are included in a logit model of Canadian ministerial appointment following four general elections $(1957,1979,1984$ and 2006) in which the prime minister was tasked with appointing a cabinet with ministerial neophytes.

Résumé. Le Conseil des ministres fédéral du Canada se démarque dans l'ensemble des démocraties parlementaires britanniques en raison du grand nombre de ministres novices qui sont nommés au Conseil alors qu'ils ne possèdent aucune expérience parlementaire ou politique antérieure. Plusieurs explications de cette anomalie ont été proposées, mais aucune démarche d'analyse ne s'est encore penchée sur la manière dont les premiers ministres du Canada arrivent à surmonter le manque d'information associé à la nomination de ministres sans expérience. Comment les premiers ministres peuvent-ils être certains d'avoir fait le bon choix? Cette étude scrute le sujet en évaluant le coefficient de survie, en cas de remaniement ministériel, pour les ministres du Conseil potentiels, mais pas encore mandatés, advenant que ces derniers survivent à certains jalons politiques précis. Ces taux de survie font partie intégrante d'un modèle de répartition des nominations ministérielles qui sont survenues à la suite de quatre élections générales $(1957,1979,1984$ et 2006) où le premier ministre a dû constituer un Conseil des ministres composé de néophytes.

This article examines the effects of expected ministerial duration on the chances that a potential minister will be appointed to cabinet. Put more specifically, the predicted survival rates (derived from the durations of previous cabinet ministers) for potential, but not yet appointed cabinet ministers, are used as an indicator of prime ministerial "guessing" when the prime minister has little or no information on which to base his decision as to which ministers to appoint to cabinet. The appointment periods which immediately follow the 1957, 1979, 1984 and 2006 Canadian federal elections are used as cases to explore this process as they are all examples of instances where a governing party was elected to office but possessed elected MPs with no or extremely limited previous cabinet experience. The results of the analysis demonstrate that predicted ministerial survival is positively related to ministerial appointment to the first cabinets of the 23rd (Diefenbaker), 31st (Clark), 33rd (Mulroney) and 39th (Harper) parliaments.

This research adds to the current work on the systematic study of elite political career paths which began in the 1990s (Dowding and Kang, 1998; Page, 1990; Woodhouse, 1994) and has more recently resulted in a collected research volume on ministerial appointments and resignations in Europe (Dowding and Dumont, 2009). Additional research in this field has made theoretical and methodological forays into the relationship between ministerial careers and party discipline (Kam and Indridason, 
2005), public opinion (Dewan and Dowding, 2005) and government stability (Dewan and Myatt, 2010; Huber and Martinez-Gallardo, 2004).

While the research conducted on ministerial careers has been impressive in recent years, both in terms of scope and number, one trend worth noting is that the majority of the published works tend to focus primarily on the subject of ministerial duration and exit. Conversely, the discussions which address ministerial appointment remain less numerous both among and within the existing literature. This trend suggests that ministerial resignations are a more attractive research topic than appointments! Yet appointments and resignations are effectively two sides of the same coin; what is currently missing from the literature is an effort to build models for comparative ministerial appointments akin to that research which has been conducted for ministerial duration and turnover.

The article is organized as follows. First, I briefly summarize a current model of ministerial careers and duration and review the ministerial appointment literature in Canada. Second, I present four event history models of Canadian ministerial duration for the periods 1867-1957, 18671979, 1867-1984 and 1867-2006. The unique contribution of this article entails using the coefficients generated by these models to estimate the predicted survival rates of every potential cabinet minister in the first Diefenbaker, Mulroney, Clark and Harper governments. The predicted survival functions which fall on the median duration of all preceding cabinet ministers are then employed in a univariate logistic regression of ministerial appointment. Finally, the article concludes with a discussion of the implications of the model and some suggestions for future research in this field of study.

\section{Review}

\section{In general}

Berlinski and colleagues offer a basic theoretical design for the study of ministerial careers. Central to this design is the concept of ministerial duration. They write,

Where a minister is shuffled out [of cabinet] he is seen to have served his time, perhaps honourably and well, but nevertheless to be replaced by somebody the prime minister believes will do a better job. Thus length of tenure must be some indicator of performance. Of course, ministers get chosen for all sorts of reasons ... but whatever the reason they are chosen, they will only progress and remain as ministers if they perform well. Of course, "perform well" can mean many things... But whatever their achievements and failings, length of tenure gives some indication of ministerial success and is thus an important variable to analyze. (2007: 246) 
Ministerial duration therefore may be understood as an indicator of ministerial success: successful ministers, generally speaking, are those ministers who "survive" in cabinet. Once ministerial duration has been established as a variable of interest, other individual and institutional level characteristics can be introduced to the model to ascertain their positive or negative effects on duration. Indeed, this is the approach that Berlinski and colleagues employ to examine British ministerial tenure; others in the comparative literature have adopted this approach as well.

With respect to ministerial hiring, Berlinski and colleagues, in subsequent contributions $(2009,2010)$ present the ministerial appointment process as a principal agent problem in which prime ministers must decide how much authority they are willing to delegate to their ministers. They argue that the level of delegation will depend on a host of individual, political and constitutional factors. Nevertheless, once the balance between the variables has been struck, one imagines that this particular cabinet is one which possesses the optimal level of survivability and by extension performance. Put another way, the jigsaw puzzle of cabinet construction may be solved by looking for pieces that ensure and promote the duration of cabinet ministers, and by extension the cabinet.

\section{In Canada}

The literature on Canadian ministerial appointments has been reviewed elsewhere and it need not be restated in full here (Kerby, 2009; White, 1998). Briefly, cabinet seats are prized objects for MPs; a cabinet seat may be a necessity required for obtaining political goals whether they be realized as policy, office or votes (Docherty, 1997, 95-96). The uniquely Canadian aspect of the ministerial appointment process relates to prime ministers. It is true that Canadian prime ministers possess the exclusive authority to appoint cabinet ministers. But they also experience the paradox of presiding over the most powerful political office in the state while they are institutionally constrained by constitutional tradition and political necessity, which demand minimal yet unspecified levels of geographic, linguistic, gender and minority representation in the cabinet (Heard, 1991, 49-50). Prime ministers are further constrained by the high levels of legislator turnover which produce a selection pool of potential ministers who are inexperienced at both the parliamentary and cabinet levels (Kerby and Blidook, 2011; Dewan and Myatt, 2010; Matland and Studlar, 2004; Sutherland, 1991).

\section{The Prime Minister's Dilemma}

In order to imagine how Diefenbaker, Mulroney, Clark and Harper resolved the problem of not knowing whom to appoint to cabinet, this 
study develops an indicator to replicate the guessing process: the predicted survival function for individual potential ministers in each government party at the beginning of their governmental tenure. To be sure, the prime ministers examined here were not and are not the sort of empirical political scientists who work out predicted survival rates for each of their ministers, but they were, and are, shrewd politicians and they must have conducted some kind of mental calculation in the absence of performance indicators to ascertain which MPs would make good ministers. $^{2}$ And, if "good ministers" are ministers who survive, then expected survivability might be just the consideration that they had in mind. Therefore, the main hypothesis tested in this paper is that government party MPs who possess predicted future survival rates of .5 or greater at the median duration point of all previous Canadian cabinet ministers should be the first ministers appointed into a new ministry. The assumptions behind the hypothesis are straightforward. In the absence of previous experience to guide them, prime ministers will theoretically examine each potential minister in their parliamentary party and compare them to an ideal average minister whose characteristics and circumstances are made up of all previous cabinet ministers who have served since Confederation. Any minister whose expected performance, measured as surviving beyond the historical median of minister duration, should be looked upon as a favourable addition to the cabinet, all other things being equal.

\section{Data, Methods and Results}

Two core datasets inform this analysis. The first consists of the population of Canadian ministerial careers for those ministers who served from Confederation in 1867 until the 2006 federal election. Prime ministers, who appoint and dismiss ministers, are not included in the model nor are unelected senators. This leaves the dataset with 587 individuals, 195 of whom served in cabinet on more than one occasion. Ministers who exited the cabinet and then returned at a later date are treated as separate observations. As a result, the dataset consists of 787 ministers. Of the 787, 243 exited the cabinet for reasons other than electoral defeat, government defeat, prime ministerial resignation or death. The data set is broken down further into four periods with one "history" for each of the cases: 1867-1957, 1867-1979, 1867-1984, 1867-2006.

The dataset also contains a series of variables which are identified in the Canadian and comparative literatures on ministerial career paths and which enhance or diminish ministerial durability. These variables fall under three general headings: individual, institutional and politicalenvironmental level characteristics. The individual level characteristics consist of age (Alderman and Cross, 1985, 1987; Atkinson and Docherty, 
1992), gender (Crossley, 1997; Desserud, 1997; Studlar and Moncrief, 1997), legal background (Porter, 1965), Quebec MP (Matheson, 1976), leadership challenger status and federal political experience (Barrie and Gibbins, 1989; Sutherland, 1991). ${ }^{3}$ The institutional and political environmental variables include minority government status (Sutherland, 1991) and the proportion of seats held by the governing party in a minister's province (Heard, 1991; White, 2005).

These data are then used to inform an event history model for each of the four periods. Event history analysis is an established and popular econometric approach commonly used by social scientists who are interested in the relationship between duration and the occurrence of an "event." Event history models are well-matched with temporal data due to their ability to accommodate censored time series as well as the violation of the assumption of normally distributed errors which typically arise when working with time-to-event data (Box-Steffensmeier and Jones, 2004). Event history models have been used to study a variety of political phenomena including government duration (King et al., 1990; Ferris and Voia, 2009), leadership duration (Bienen and van de Walle, 1992), ministerial duration (Berlinski et al., 2007, 2010) and ministerial appointment (Kerby, 2009). This article employs a particular class of event history model: a semi parametric Cox proportional hazard model. The Cox model is adopted because its flexibility with respect to the parameterization of the hazard function is particularly well-suited when there are no ex-ante assumptions about the shape of the distribution of time of an individual's risk of experiencing a terminal event. ${ }^{4}$

Once specified, the event history model is able to relate cabinet ministers' individual and political characteristics, as well as the characteristics of the political environment in which they serve, to the time it takes to exit the cabinet. Duration is recorded as the span that elapses from cabinet appointment until cabinet exit. Ministers who die in office, are defeated in a general election or exit the cabinet when the prime minister ceases to be the leader of the governing party are treated as censored.

The primary statistic of interest when using event history analysis is the hazard rate, which refers to the instantaneous probability that an individual will experience an event at a point in time given that the individual has "survived" up until that point in time. The hazard rate is expressed as

$$
h(t)=\lim _{\Delta t \rightarrow 0} \frac{\operatorname{Pr}(t \leq T \leq t+\Delta t \mid T \geq t)}{\Delta t}
$$

which is the probability that an individual will fail at time $t$ conditional on having survived until that time. By focusing on the hazard rate one is able to ask, "What is the likelihood that a cabinet minister will exit the 
cabinet at any point in time since becoming a minister, given how long he has served in cabinet, conditional on a series of covariates?" The hazard rate is an important statistic for this paper as the survivor function, which is used as a predictor of ministerial appointment, is derived from the hazard rate of ministerial duration.

The results of the event history models are found in Table 1. These models confirm the generally held assumptions regarding ministerial duration and exit in Canada: political experience measured as years served in the House of Commons reduces the hazard of ministerial exit as does a professional background in law. Additionally, the strength of the governing party in a minister's province is negatively related to the hazard rate of ministerial exit. The exception is the leadership challenger variable in the 1867-1957 model which counterintuitively predicts that leadership challengers face a higher hazard of ministerial exit than non-challengers. ${ }^{5}$

The event history models of ministerial duration are then used to estimate the predicted survival rates for those MPs elected to the first Diefenbaker, Clark, Mulroney and Harper government parties. This second dataset consists of the MPs who make up the selection pool of potential ministers from which the prime ministers will choose to form their

TABLE 1

Cox Proportional Hazards Model

\begin{tabular}{lcccc}
\hline \hline & $1867-1957$ & $1867-1979$ & $1867-1984$ & $1867-2006$ \\
\hline Age & 1.053 & 0.874 & 0.901 & $0.807^{* *}$ \\
& $(0.15)$ & $(0.10)$ & $(0.10)$ & $(0.07)$ \\
Age2 & 0.999 & 1.001 & 1.001 & $1.002^{* *}$ \\
& $(0.00)$ & $(0.00)$ & $(0.00)$ & $(0.00)$ \\
Legal Background & 0.229 & $0.507^{*}$ & $0.502^{*}$ & $0.582^{* *}$ \\
& $(0.17)$ & $(0.15)$ & $(0.14)$ & $(0.11)$ \\
Quebec Minister & 1.103 & 1.111 & 1.099 & 1.127 \\
Leadership Challenger & $(0.24)$ & $(0.19)$ & $(0.19)$ & $(0.16)$ \\
& 1.882 & 0.955 & 0.912 & 0.715 \\
Minority Government & $(0.87)$ & $(0.34)$ & $(0.32)$ & $(0.23)$ \\
& 1.787 & 1.172 & 1.176 & 1.506 \\
Federal Experience & $(0.88)$ & $(0.46)$ & $(0.46)$ & $(0.53)$ \\
& $0.956^{* *}$ & $0.966^{* *}$ & $0.962^{* *}$ & $0.961^{* * *}$ \\
Govt. Seats in Province & $(0.01)$ & $(0.01)$ & $(0.01)$ & $(0.01)$ \\
Female & $1.016^{* * *}$ & $1.013^{* * *}$ & $1.013^{* * *}$ & $1.011^{* * *}$ \\
& $(0.00)$ & $(0.00)$ & $(0.00)$ & $(0.00)$ \\
Failures & & 0.293 & 0.464 & 0.635 \\
Obs & 117 & $(0.30)$ & $(0.34)$ & $(0.19)$ \\
& 351 & 171 & 178 & 243 \\
\end{tabular}

Hazard Ratios Reported

${ }^{*} p<0.05,{ }^{* *} p<0.01,{ }^{* * *} p<0.001$ 
cabinets. The MPs' predicted survivor rates at the median ministerial duration are included in this second dataset and subsequently in a logit model of ministerial appointment.

Figures 1-4 present the graphical representations of the survivor functions for each case's selection pool. The graphs are divided on the $\mathrm{x}$ axis by a line which marks the median duration for all uncensored cabinet ministers who served up until the beginning of the parliament under consideration; the y axis, which records the survival function is bisected at the .5 mark, the point at which one-half of the ministers have exited the dataset. I propose that the quadrant of interest is the top right-hand quadrant which consists of those MPs who have a predicted survivor function of .5 or greater, on or after the median duration of uncensored cabinet ministers (the top right quadrant appears as the right-hand figure in each graph). If ministerial duration is positively related to ministerial performance, as Berlinski and colleagues suggest, then one expects prime ministers to select, at the very least, those ministers whose predicted cabinet survival function falls into the upper right-hand quadrant. Indeed, the positive correlation coefficients in Tables 2 to 5 indicate that there is a moderate positive correlation between predicted survivor functions and ministerial appointment in each of the cases. In the absence of MPs with

\section{FIGURE 1}

Diefenbaker Predicted Survival Curves
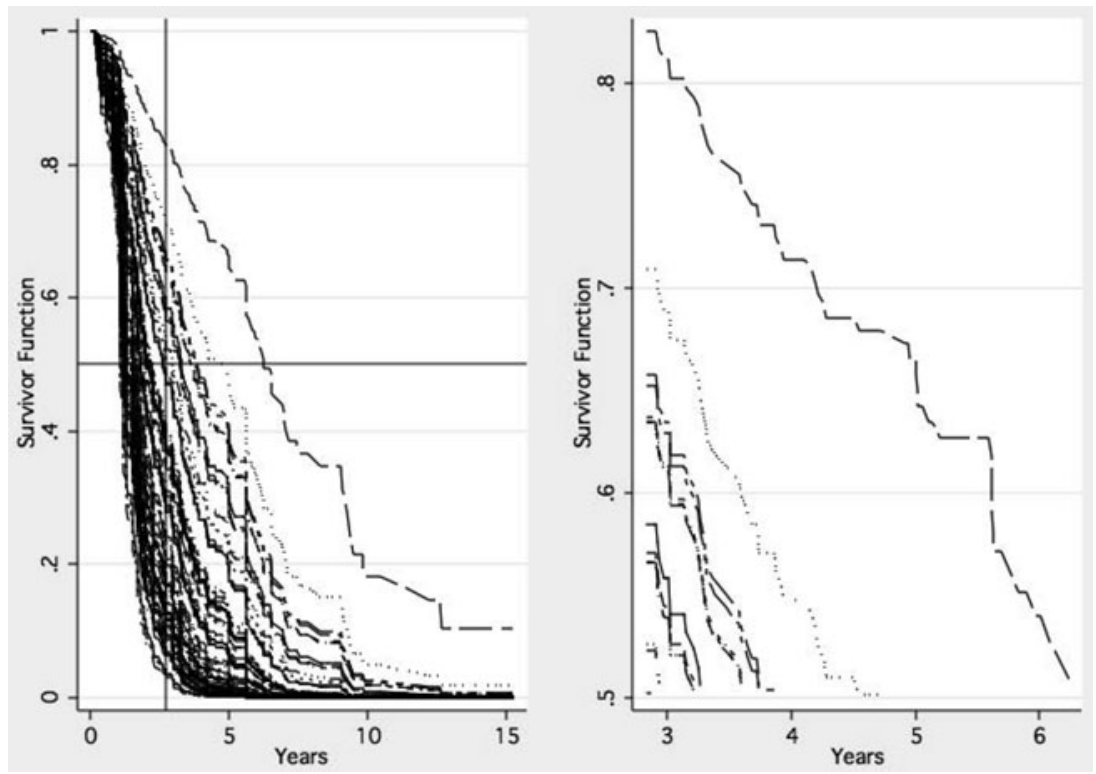
FiguRE 2

Clark Predicted Survival Curves
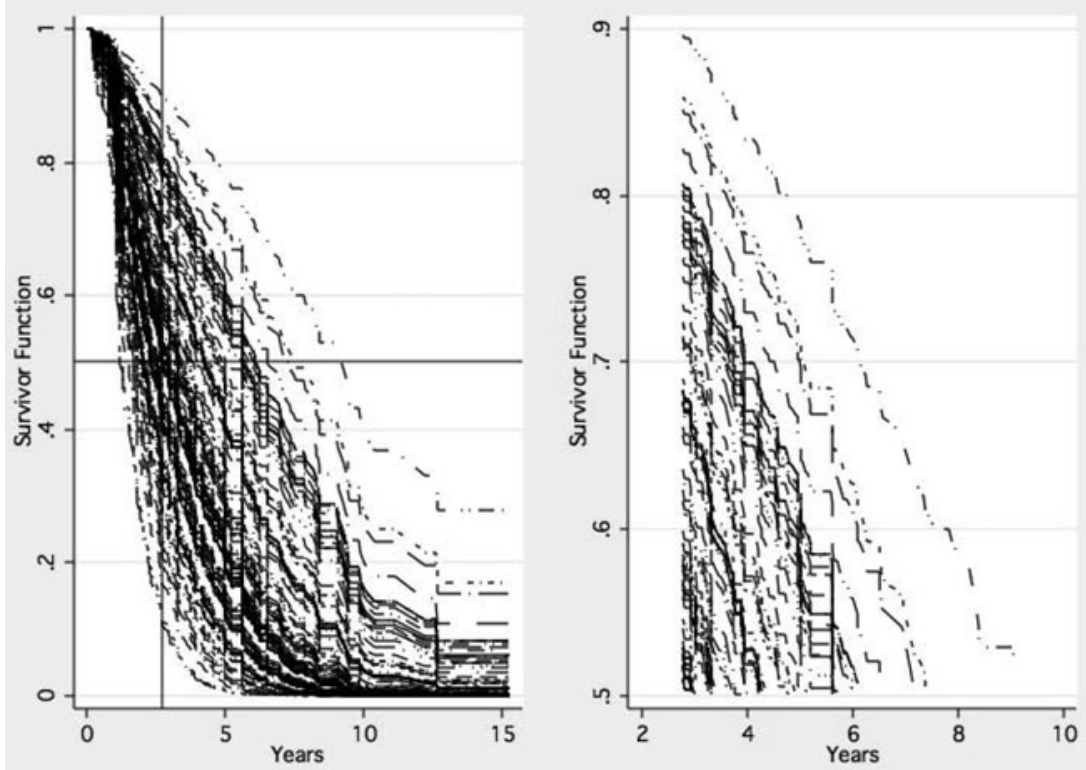

FiguRe 3

Mulroney Predicted Survival Curves
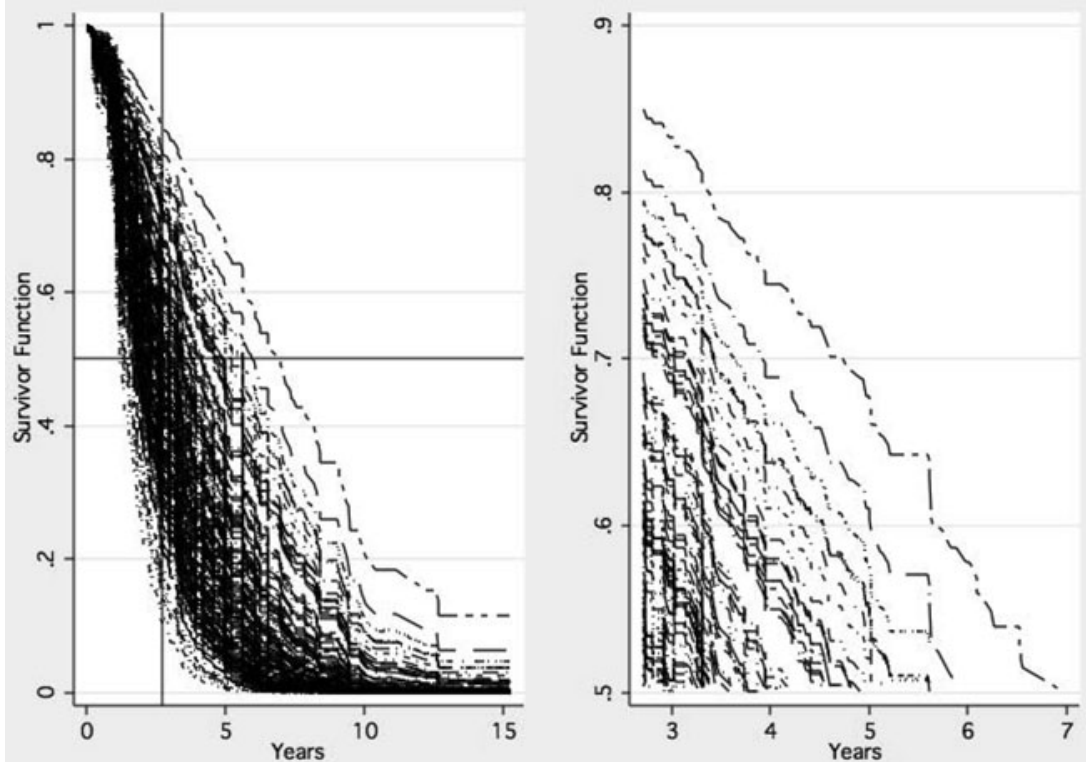
FIGURE 4

Harper Predicted Survival Curves
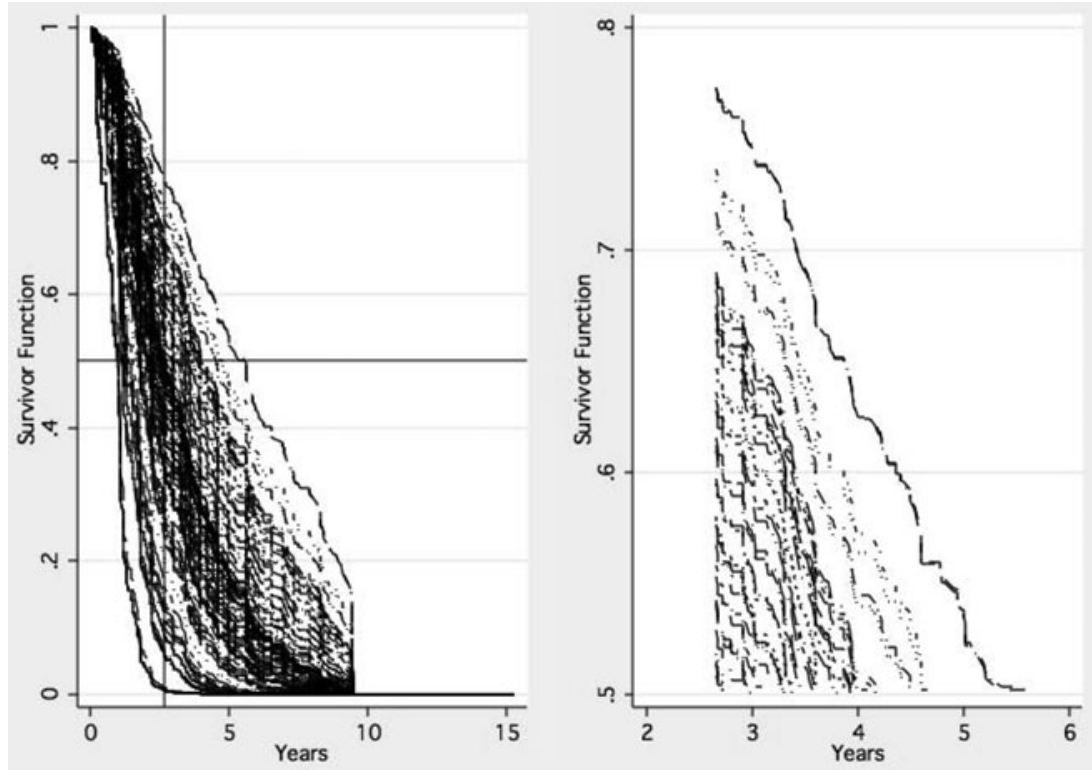

significant cabinet experience, it appears that Diefenbaker, Mulroney, Clark and Harper may have hedged their bets by appointing cabinet ministers whose predicted ministerial durability was above average.

Table 6 presents the logit model of ministerial appointment for each prime minister's first cabinet and includes the predicted survival function at the median ministerial duration as the independent variable of interest. The exponentiated coefficients (odds ratios) are presented in order to facilitate interpretation. Variation in the four models suggests that the prime ministers may have different interests or priorities at heart when

TABle 2

Cross-correlation Table: 1957

\begin{tabular}{|c|c|c|}
\hline Variables & $\begin{array}{l}\text { Appointed } \\
\text { Minister }\end{array}$ & $\begin{array}{l}\text { Predicted } \\
\text { Survivor } \\
\text { Function }\end{array}$ \\
\hline Appointed Minister & 1.000 & \\
\hline Predicted Survivor Function & $\begin{array}{c}0.375 \\
(0.000)\end{array}$ & 1.000 \\
\hline
\end{tabular}


TABLE 3

Cross-correlation Table: 1979

\begin{tabular}{|c|c|c|}
\hline Variables & $\begin{array}{c}\text { Appointed } \\
\text { Minister }\end{array}$ & $\begin{array}{l}\text { Predicted } \\
\text { Survivor } \\
\text { Function }\end{array}$ \\
\hline Appointed Minister & 1.000 & \\
\hline Predicted Survivor Function & $\begin{array}{c}0.291 \\
(0.000)\end{array}$ & 1.000 \\
\hline
\end{tabular}

they appointed their first cabinets. The odds ratios for the predicted survivor function for the Progressive Conservative MPs under Diefenbaker and Mulroney's leadership were both negative. For each percentage point increase in the predicted survivor function, the odds of ministerial appointment decreased by 18 percent for Diefenbaker's ministrables and four percent for Mulroney's ministrables. Conversely the predicted survivor function coefficients for the Progressive Conservatives under Clark and the Conservatives under Harper are positive. When converted to odds ratios we see that each percentage point increase in the predicted survivor function increases an MP's odds of cabinet appointment by 8 per cent for Progressive Conservative MPs in 1979 and 3 per cent for Conservative MPs in 2006.

Negative coefficients for the predicted survivor functions in the Diefenbaker and Mulroney cabinets suggest that expected ministerial durability may have been less of a concern for these prime ministers. This may make sense, particularly for Mulroney. At the time of his party's electoral success, Mulroney presided over a very large majority government; he could afford to take risks with respect to cabinet appointment without any threat that the opposition parties would bring down the government. Additionally, the size of the parliamentary party meant that there was an ample supply of replacement ministers to fill the cabinet seats of ministers who failed to impress. Mulroney was also in an unusual posi-

TABLE 4

Cross-correlation Table: 1984

\begin{tabular}{lcc}
\hline \hline Variables & $\begin{array}{c}\text { Appointed } \\
\text { Minister }\end{array}$ & $\begin{array}{r}\text { Predicted } \\
\text { Survivor } \\
\text { Function }\end{array}$ \\
\hline Appointed Minister & 1.000 & \\
Predicted Survivor Function & 0.315 & 1.000 \\
& $(0.000)$ & \\
\hline
\end{tabular}


TABLE 5

Cross-correlation Table: 2006

\begin{tabular}{lcc}
\hline \hline Variables & $\begin{array}{c}\text { Appointed } \\
\text { Minister }\end{array}$ & $\begin{array}{r}\text { Predicted } \\
\text { Survivor } \\
\text { Function }\end{array}$ \\
\hline Appointed Minister & 1.000 & \\
Predicted Survivor Function & 0.333 & 1.000 \\
& $(0.000)$ & \\
\hline
\end{tabular}

tion in so far as his pool of potential ministers contained large number of political and ministerial neophytes. He could not rely on the ministrables' previous political record of success or failure because that record simply did not exist. Lastly, Mulroney assembled his cabinet after a prolonged hiatus from government (leaving the Clark interlude aside); he was indebted to individuals and factions within his party, particularly Quebec nationalists, who either supported his leadership and expected to be rewarded with a cabinet seat or had served the party in the dark days of opposition bench purgatory and expected a cabinet seat regardless of their expected survivability.

In the case of Diefenbaker, the explanation is less obvious. Diefenbaker's story in 1957 might have been quite similar to Mulroney's in 1984 had the 1958 election results occurred in 1957. Then the explanations that buttress the coefficients in the 1984 model could equally apply to the 1957 model. But the Progressive Conservatives only secured a minority government in 1957 and we should have expected Diefenbaker to be more cautious when appointing his ministers. Although, and like Mulroney, the Progressive Conservative's long absence from government meant that Diefenbaker had a number of party loyalists who needed to be rewarded regardless of their suitability or expected durability. As Diefenbaker himself noted that he was obliged to fill his cabinet with his political enemies (Punnett, 1977: 56, 63).

With respect to the Clark and Harper governments, the positive coefficients for the predicted survival rate variable indicate that these prime ministers may have been more selective when choosing their ministers. Both prime ministers presided over minority governments in their first terms; the need to stock their cabinets with ministers whose durability reflected experience, discretion and competence surely trumped the need to satisfy party loyalties and demands.

\section{Conclusion}

This study of ministerial appointments further expands our understanding of parliamentary process as well as elite career paths. The research 


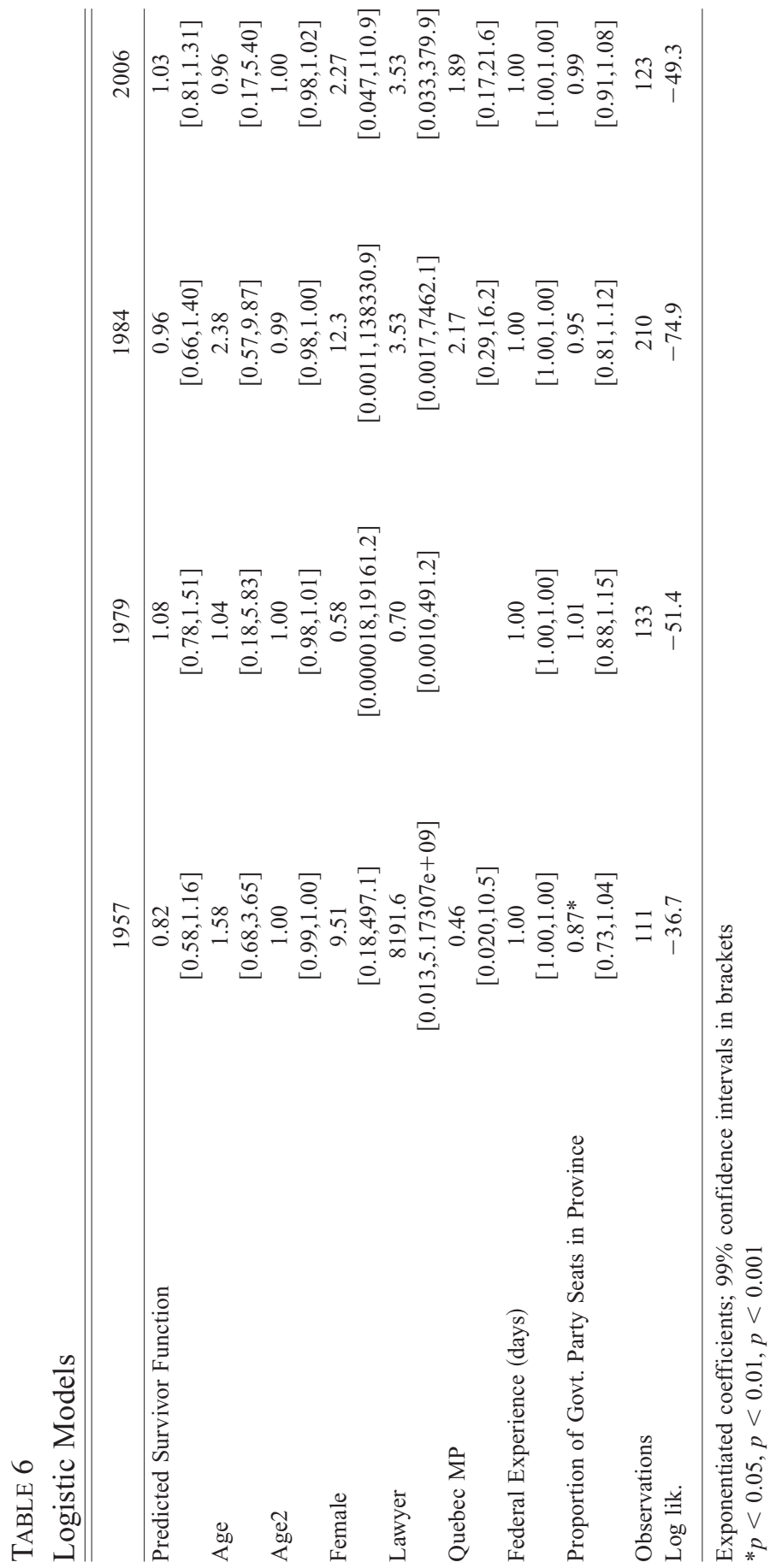


introduced in this paper takes a step towards a deeper examination of ministerial appointments for a single case, Canada, particularly with respect to those incidents where prime ministers are faced with the task of forming a cabinet which is made up of ministerial neophytes.

The results of the logit models are encouraging in so far as they both confirm and challenge the main hypothesis. True, the Canadian prime ministers examined in this study appoint ministers who possess the historical qualities associated with ministerial durability. As the Mulroney but not necessarily the Diefenbaker cases demonstrate, however, the extent to which prime ministers whose parties command large parliamentary majorities are constrained by expected duration is limited. These prime ministers, by virtue of their majorities, can afford to buck the trend!

If cabinet survival is related to ministerial success then one might argue that MPs who are appointed to cabinet are those who are most expected to succeed as cabinet ministers. Of course, the theoretical goal of an immortal cabinet is hardly a desirable state of affairs in a political system based on responsible government and the twin pillars of collective and ministerial responsibility. The absence of periodic movement in and out of the cabinet, should the circumstances and opposition parties demand it, may be indicative of a government that is unresponsive to Parliament. Fortunately, this is not the case; cabinet promotion and demotion is reasonably frequent.

If the model results appear somewhat deterministic, it is worth remembering that the correlation coefficient for cabinet appointment and predicted survivability was only moderately positive, which suggests that other factors are likely at play. These factors may include prime ministerial miscalculation as well as the influence of unique Canadian constitutional conventions that stipulate that underrepresented groups "should" be appointed to cabinet, even if their predicted survivability is low. Also, prime ministers will occasionally appoint duds, risky bets or political hopefuls in order to satisfy party demands or simply as a consequence of poor judgment.

Furthermore, it is also worth remembering that the political reality of day-to-day politics, the unanticipated surprises and exogenous shocks can upend even the most durable of ministers, let alone those ministers with limited political experience. Just because a minister is expected to survive does not mean that they will survive. Both Diefenbaker and Mulroney presided over cabinets which could hardly be described as bulletproof. Stephen Harper's dismissal of Rona Ambrose, Maxime Bernier and Helena Guergis suggest that even underrepresentativeness in the government ranks will not save a minister whose time is up due to political scandal or poor portfolio management.

At this early stage of the research process, it is necessarily to highlight the next steps which require attention. I highly suspect that the event 
history model which is used to estimate the predicted survival rates needs to be better specified. There are undoubtedly missing variables which should be included: religious background, regional ministers, important portfolios, previous ministerial experience, all come to mind. Additionally, Huber and Martinez-Gallardo's (2008) recent foray into the realm of competing risk event history models suggests different forms of ministerial exit should be considered when estimating the predicted survival functions. Whether a minister jumps or is pushed from cabinet likely has a different effect on the estimation of the predicted survival function. Relatedly, a multinomial logistic model may be employed in the future to estimate the odds of appointment to a particular cabinet rank or individual portfolio.

The possibility of an opposition party coalition sparked by the Conservative government's prorogation of parliament in 2008 raises another opportunity for further research: how would the leader of a hypothetical Canadian coalition government select their ministers? Formal government formation models may help to determine the size of such governments as well as the parties that are likely to be included and the portfolios assigned to each party, but these models do not make predictions as to the specific individuals appointed to cabinet (Laver and Schofield, 1998; Laver and Shepsle, 1996). An updated version of the model presented in this article, one which includes the potential cabinet ministers drawn from the likely coalition partners may be appropriate should the opportunity for coalition government present itself again in the future.

Consideration of these additional factors will only help to provide clearer insights into the process of ministerial appointment and prime ministerial decision making in Canada and elsewhere.

\section{Notes}

1 The 31 st parliament was capped at 66 days; it was cut short by the government's failure to pass its first budget; the Liberals returned to power in the ensuing general election.

2 Brian Mulroney and Erik Nielsen created score cards which were used to record and assess ministerial qualities among the 1984 ministrables (Nielsen, 1989).

3 Gender is not included as no women were appointed to cabinet during the 18671957 period.

4 A shared frailty specification is also employed to account for group specific effects which may otherwise lead to misspecified estimates of duration dependence (Hougaard, 2000; Huber and Martinez-Gallardo, 2008).

5 The positive coefficient may be explained by the fact that official leadership conventions were not held until 1921 for the Liberal party and 1927 for the Conservative party (predecessor of the Progressive Conservative party). Prior to the introduction of leadership conventions party leaders were selected by the parliamentary party and a consensus was typically established on who would best serve as the party leader. Prior to 1921-1927 leadership challengers were identified as those individuals who were known leadership potentials as identified in the Canadian Historical Biography. 
Alternatively, the leadership challenger results for the 1867-1957 model may be explained by Kam and Indridason's finding which suggest that prime ministers use cabinet reshuffles to fend off challengers to their leadership (Kam and Indridason, 2005; Indridason and Kam, 2008).

\section{References}

Alderman, R.K. and J.A. Cross. 1985. "The Reluctant Knife: Reflections on the Prime Minister's Power." Parliamentary Affairs 38: 387-408.

Alderman, R.K. and J.A. Cross. 1987. "The Timing of Cabinet Reshuffles." Parliamentary Affairs 40 (1): 1-19.

Atkinson, Michael M. and David C. Docherty. 1992. "Moving Right Along: The Roots of Amateurism in the Canadian House of Commons." Canadian Journal of Political Science/Revue canadienne de science politique 25 (2): 295-318.

Barrie, Doreen and Roger Gibbins. 1989. "Parliamentary Careers in the Canadian Federal State." Canadian Journal of Political Science 22 (1): 137-45.

Berlinski, Samuel, Torun Dewan and Keith Dowding. 2007. "The Length of Ministerial Tenure in the UK 1945-1997." British Journal of Political Science 37 (2): 245-62.

Berlinski, Samuel, Torun Dewan and Keith Dowding. 2010. "The Impact of Individual and Collective Performance on Ministerial Tenure." The Journal of Politics 72 (2): 559-71.

Berlinski, Samuel, Torun Dewan, Keith Dowding and Gita Subrahmanyan. 2009. "Choosing, moving and resigning at Westminster, UK." In The Selection of Ministers in Europe: Hiring and Firing, ed. Keith Dowding and Patrick Dumont. Abingdon: Routledge.

Bienen, Henry and Nicolas van de Walle. 1992. "A Proportional Hazard Model of Leadership Duration." Journal of Politics 54: 685-719.

Box-Steffensmeier, Janet M. and Bradford S. Jones. 2004. Event History Modeling: A Guide for Social Scientists. Cambridge: Cambridge University Press.

Crossley, John. 1997. "Picture This: Women Politicians Hold Key Posts in Prince Edward Island." In In the Presences of Women: Representation in Canadian Governments, ed. Jane Arscott and Linda Trimble. Toronto: Harcourt Brace Canada.

Davey, Clark. 1957. "Diefenbaker Appoints 2 Ministers, 8 Aides." The Globe and Mail (Toronto), August 8, 2.

Desserud, Don. 1997. "Women in New Brunswick Politics: Waiting for the Third Wave." In In the Presence of Women: Representation in Canadian Governments, ed. Jane Arscott and Linda Trimble. Toronto: Harcourt Brace Canada.

Dewan, Torun and Keith Dowding. 2005. "The Corrective Effect of Ministerial Resignations on Government Popularity." American Journal of Political Science 49 (1): 46-56.

Dewan, Torun and David Myatt. 2010. "The Declining Talent Pool of Government." American Journal of Political Science 54 (2): 267-86.

Docherty, David C. 1997. Mr. Smith Goes to Ottawa: Life in the House of Commons. Vancouver: University of British Columbia Press.

Dowding, Keith and Patrick Dumont, eds. 2009. The Selection of Ministers in Europe: Hiring and Firing. Abingdon: Routledge.

Dowding, Keith and Won-Taek Kang. 1998. "Ministerial Resignations 1945-97." Public Administration 76: 411-29.

Ferris, J. Stephen and Marcel-Cristian Voia. 2009. "What Determines the Length of a Typical Canadian Parliamentary Government?" Canadian Journal of Political Science 42 (4): 881-910.

Heard, Andrew. 1991. Canadian Constitutional Conventions: The Marriage of Law and Politics. Toronto: Oxford University Press. 
Hougaard, Philip. 2000. Analysis of Multivariate Survival Data. New York: Springer.

Huber, John D. and Cecilia Martinez-Gallardo. 2004. "Cabinet Instability and the Accumulation of Experience: The French Fourth and Fifth Republics in Comparative Perspective." British Journal of Political Science 34: 27-48.

Huber, John D. and Cecilia Martinez-Gallardo. 2008. "Replacing Cabinet Ministers: Patterns of Ministerial Stability in Parliamentary Democracy." American Political Science Review 102 (2): 169-80.

Indridason, Indridi and Christopher Kam. 2008. "Cabinet Reshuffles and Ministerial Drift." British Journal of Political Science 38 (4): 621-56.

Kam, Christopher and Indridi Indridason. 2005. "The Timing of Cabinet Reshuffles in Five Westminster Parliamentary Systems.” Legislative Studies Quarterly 30: 327-63.

Kerby, Matthew. 2009. "Worth the Wait: The determinants of ministerial appointment in Canada, 1935-2008." Canadian Journal of Political Science 42 (3): 593-611.

Kerby, Matthew and Kelly Blidook. 2011. "It's Not You, It's Me: Determinants of Voluntary Legislative Turnover in Canada" Legislative Studies Quarterly 36 (4): 621-43.

King, Gary, James E. Alt, Nancy Elizabeth Burns and Michael Laver. 1990. "A Unified Model of Cabinet Dissolution in Parliamentary Democracies." American Journal of Political Science 34 (3): 846-71.

Laver, Michael and Norman Schofield. 1998. Multiparty Government: The Politics of Coalitions in Europe. Ann Arbor: The University of Michigan Press.

Laver, Michael and Kenneth Shepsle. 1996. Making and Breaking Governments: Cabinets and Legislatures in Parliamentary Governments. Cambridge: Cambridge University Press.

Matheson, William A. 1976. The Prime Minister and the Cabinet. Toronto: Methuen.

Matland, Richard E. and Donley T. Studlar. 2004. "Determinants of Legislative Turnover: A Cross-National Analysis." British Journal of Political Science 34: 87-108.

Nielsen, Erik. 1989. The House Is Not a Home. Toronto: Macmillan of Canada.

Page, Barbara. 1990. "Ministerial Resignation and Individual Ministerial Responsibility in Australia 1976-1989." Journal of Commonwealth and Comparative Politics 28: 141-61.

Porter, John. 1965. The Vertical Mosaic. Toronto: University of Toronto Press.

Punnett, Robert Malcolm. 1977. The Prime Minister in Canadian Government and Politics. Toronto: Macmillan.

Studlar, Donley T. and Gary Moncrief. 1997. "The Recruitment of Women Cabinet Ministers in the Canadian Provinces." Governance: An International Journal of Policy and Administration 10: 67-81.

Sutherland, S.L. 1991. "The Consequences of Electoral Volatility: Inexperienced Ministers 1949-90." In Representation, Integration and Political Parties in Canada, ed. Herman Bakvis. Ottawa: Royal Commission on Electoral Reform and Party Financing and Canada Communications Group, Supply and Services Canada and Dundurn Press.

White, Graham. 1998. "Shorter Measure: The changing ministerial career in Canada." Canadian Public Administration 41 (3): 369-94.

White, Graham. 2005. Cabinets and First Ministers. Vancouver: UBC Press.

Woodhouse, Diana. 1994. Ministers and Parliament: Accountability in Theory and Practice. Oxford: Clarendon Press. 